\title{
The Evolution of Ownersip Patterns in Franchise Systems
}

\author{
FRANCINE LAFONTAINE \\ University of Michigan \\ PATRICK J. KAUFMANN \\ Georgia State University
}

Two sets of competing theories have been proposed to explain the existence of franchising; one set based on resource constraints and another on incentives issues. As individual franchise systems mature, these theories predict different patterns in the evolution of the mix of franchised and company-owned outlets. In this paper, we report the results of an empirical study of franchise system evolution. The findings generally support the incentives-based rationale for franchising, but they also support a modified resource constraint theory, one which recognizes the synergistic effects of dual distribution.

In their seminal article in the Journal of Retailing, Oxenfeldt and Kelly (1969) argued that franchise systems, like other organizations, have life cycles that predict various aspects of their structure and processes. More specifically, they reasoned that the resource scarcity that drove expanding chain retailers to embrace franchising early in their system's life cycle would lessen as the system became more established. The costs associated with managing franchisees gradually would outweigh the benefits associated with the resources that the franchisees provided, and the systems would move toward chains of company-owned, rather than franchised, outlets.

Although the specifics of Oxenfeldt and Kelly's hypothesis have been questioned (see Dant, Kaufmann, and Paswan 1992 for a review of the empirical literature on this subject), its underlying insight remains compelling. Resources and motivations are likely to change over time in a franchise system, and such changes should impact the ownership structure of that system. In this paper, we explore some of the changes that take place within franchise systems as they proceed from the granting of the first franchise to maturity. The primary purpose is to determine whether the pattern of unit ownership, that is the mix of companyowned and franchised outlets, changes in a predictable manner over time.

Francine Lafontaine, University of Michigan, School of Business, Ann Arbor, MI 48109. Patrick J. Kaufmann, Georgia State University, Department of Marketing, Atlanta, GA 30303.

Journal of Retailing, Volume 70, Number 2, pp. 97-113, ISSN 0022-4359

Copyright $\odot 1994$ by New York University. All rights of reproduction in any form reserved. 
Aside from the Oxenfeldt and Kelly resource constraint argument, the franchising literature offers mostly arguments centering on incentive issues to explain the existence and use of franchise contracts. ${ }^{1}$ Both the transaction costs approach and principal-agent theory have emphasized the role of franchisee incentives, though the need to give incentives to franchisors and the effect this has on the design and use of franchise contracts also have been discussed (e.g., Rubin 1978; Mathewson and Winter 1985; Lal 1990; and Bhattacharyya and Lafontaine 1992). As noted by Bergen, Dutta and Walker (1992), the literature emphasizing incentives has been mostly static, and has had little to say about the dynamics of the ownership mix. Nevertheless, as in the Oxenfeldt and Kelly argument, it is possible to borrow from static theory in order to preform the analysis of franchise system evolution. In other words, if the antecedent factors predictive of franchising change as the system matures, theory would predict changes in the decision to franchise units or operate them as company-owned outlets.

In this paper, we exploit the way in which these antecedent factors are likely to change as a franchised system matures to suggest testable competing hypotheses derived from both the resource constraint and incentive-based explanations for franchising. We show how these two approaches lead to different predictions as to the expected movement of the ownership mix (i.e., the proportion of company-owned and franchised units in the overall system) as a system matures. We then proceed to test these hypotheses using primary survey data.

The paper is organized as follows. In the next section, we review the theoretical perspectives in more detail and derive our hypotheses. We then briefly summarize the existing empirical evidence relating to these hypotheses. Next, we report and discuss the results of our study of 130 franchising companies. The last section contains concluding remarks.

It should be noted from the outset that we are not speaking here about the general evolution of franchising as an industry or as an organizational form. Rather, our focus is on how the structure of individual franchise systems (as super-organizations) evolve as they move from the initial stages of their life cycle to maturity.

\section{OWNERSHIP PATTERNS AND SYSTEM EVOLUTION}

Why retailers franchise outlets rather than owning and operating them directly has been a central question in the franchising literature. According to existing theories, the reasons for choosing to franchise fall into two main categories: (1) resource constraints; and (2) incentive issues. Here, we examine the basic arguments relating these factors to the use of franchising, and derive predictions as to how changes in these over time are likely to impact franchisors' choices.

\section{Resource Constraints}

The resource constraint argument, first put forward by Oxenfeldt and Kelly (1969), holds that franchisors use franchising to obtain access to some resources that franchisees own. Oxenfeldt and Kelly suggested that the resource provided by franchisees may be financial capital, human capital, or managerial talent. Similarly, Norton (1988) emphasized the 
franchisor's need for human capital and managerial talent as a reason for franchising, while Minkler (1990) focused on the franchisee's capacity to provide local market expertise.

Underlying this resource constraint argument is the assumption that retailers prefer to own their outlets; it is only because that option is unavailable to them that they choose to franchise. If we assume such a preference, for argument sake, (an assumption we relax below), the next step is to determine if and when such ownership is possible. New niche retailers with unique concepts often find market preemption and rapid expansion to be key components of their marketing strategy (Gilman 1990). But rapid growth requires significant increases in human and financial capital, as well as expertise in unfamiliar markets, resources to which a young organization may not have easy access.

As noted by Norton (1988), franchising is one way for such firms to gain access to these resources. For example, while managers with the talent to operate new outlets are often difficult to develop from within, especially early in an organization's history, franchisees often provide ready sources of such human capital. Franchisees, typically drawn from the markets into which the chain intends to expand, also provide important real estate and demand expertise otherwise unavailable to the retailer (Bush, Tatham and Hair 1976; Minkler 1990). Moreover, new retail chains may be unable to generate enough cash internally to expand at the desired rate. Selling franchises is a way to obtain more expansion capital. Not only do the franchise fees generate cash that the franchisor needs to create the supporting infra-structure for the growing system, but the franchisees also typically provide the fixed investment for equipment, signage, and often, buildings and land. It is clear that franchisors perceive growth as an important reason for franchising as indicated by survey research (Lafontaine 1992b; Dant 1994).

Rubin (1978) has argued that, because of differences in risk, selling shares in the whole chain is a more efficient solution to the capital problem than franchising which, in reality, amounts to selling shares in individual outlets. Thus he notes that the shortage of financial capital experienced by a new chain should not cause the retailer to franchise its outlets, but rather to raise funds from investors. In his view, if a firm decides to franchise, it does so because of reasons other than access to capital.

Examining Rubin's (1978) argument, Lafontainc (1992a) pointed out that franchising may be a less expensive source of capital if there are incentive issues at the outlet level. She argues that if managers lack incentives to exert effort, investors with a portfolio of shares from all outlets are likely to demand higher rates of return, even if their investment is less risky, than they would on the capital invested in a single store that they manage themselves. Hence, capital may after all be more efficiently obtained from franchisees than from investors.

Not included in Rubin's or Lafontaine's analysis is the value the entrepreneur-retailer may place on maintaining personal and "unencumbered control" over the strategic direction of his or her organization. Combined with the fact that in new chains the shares sold are likely to be held by a few large shareholders, control over the operations of widely dispersed and relatively small franchisees may be more easy to maintain than control over corporate strategy in a boardroom inhabited by heavily invested venture capitalists. Initially, therefore, when capital is scarce, retailers might opt for franchising even if that source of capital is ostensibly somewhat more costly.

Whether franchising is initially the most efficient source of capital or not, as the system matures, the financial and human capital constraints are gradually relaxed. When this occurs, 
the resource constraints argument predicts that the proportion of company-owned outlets will increase as the franchisor moves toward a completely company-owned chain. Only the marginal outlets, e.g., those located far from company headquarters, or those facing low demand, will remain in the hands of franchisees. Although new outlets will be opened as company-owned units from the outset, changes in the ownership of existing outlets may be slowed by lengthy franchise agreements and the difficulty in negotiating reacquisitions prior to expiration. These lag effects, therefore, should lead franchisors to perceive their desired proportion of company-owned outlets (i.e., that proportion they view as optimal for their system) typically to exceed the current mix.

The resource constraint argument, therefore, leads to the following set of testable implications:

H1A: The proportion of company-owned stores desired by franchisors should be quite high, approaching 100\%.

H2A: The proportion of company-owned stores should increase with the age of the franchisor. ${ }^{2}$

H3A: The desired proportion of company-owned stores should never be below the current proportion.

H2A and H3A are derived here under the assumption that early in its history the firm does not have good access to financial or human capital from sources other than franchisees. Large parent corporations, to which some franchise systems belong, are a potential alternative source of these resources. As a result, $\mathrm{H2A}$ and $\mathrm{H3A}$ need not hold for franchisors that are subsidiaries of larger corporations. If these firms have better access to resources, or are not as constrained as other new franchisors are, we should find that:

H4A: The proportion of company-owned stores is greater for franchisors that are subsidiaries of large corporations than for non-subsidiary franchisors of similar age.

\section{Incentives}

Another general set of explanations for franchising, emphasized in both the transaction costs and the principal-agent literature, has been based on the need to motivate the franchisee (or the franchisee and the franchisor) to exert the proper amount of effort to make the business a success (Williamson 1985; Rubin 1978; Mathewson and Winter 1985). By giving the franchisee a claim to a large part of the profits of the outlet, the franchisor is assured that the franchisee will want to put in the right amount of effort in managing the store (see e.g., Caves and Murphy 1976; Mathewson and Winter 1985; Brickley and Dark 1987; Norton 1988; Lafontaine 1992a; and Sen 1993). ${ }^{3}$ By also including in the contract a variable payment to 
the franchisor, (i.e., royalties) based on outlet sales, the franchisee is assured that the franchisor also has incentives to put sufficient effort into the management of the overall system (Rubin 1978; Muris 1981; Blair and Kaserman 1982; Mathewson and Winter 1985; Lal 1990; Bhattacharyya and Lafontaine 1992). In other words, this line of reasoning attacks the underlying assumption of the resource constraint argument by suggesting that the alignment of franchisor and franchisee interests attained through the franchise agreement produces a more efficient operation than could be achieved through vertical integration and internal control.

Incentive-based arguments, therefore, suggest that franchising should be the preferred organizational form throughout the life of a retail chain: the chain would start with a limited number of prototype company-owned units and move basically toward a fully franchised chain (Martin 1988). ${ }^{4}$ As before, because of the time it takes to effect changes in ownership, this shift toward franchising would take some time, leading to the observation of a lag effect.

In summary, incentive-based explanations for franchising lead to exactly the opposite implications from those obtained in first three hypotheses described in the previous section.

H1B: The proportion of company-owned stores desired by franchisors should be quite low, approaching $0 \%$.

H2B: The proportion of company-owned stores should decrease with the age of the franchisor. ${ }^{5}$

H3B: The desired proportion of company-owned stores should never be above the current proportion.

Moreover, because the incentive arguments for franchising are unrelated to capital constraints, whether a franchisor has access to capital through a larger parent corporation or not is irrelevant to the franchising decision. Thus,

H4B: The proportion of company-owned stores should be unrelated to whether the franchisor is the subsidiary of a larger corporation.

\section{Stable Benefits of Mixed Ownership}

As indicated above, the resource constraint argument for franchising assumes that company-ownership is the preferred method of operation. The incentive argument suggests that franchising should be the preferred method. In a unique approach to this question, Bradach and Eccles (1989) incorporate the concept of tapered integration from economics to argue that firms often strategically employ "plural forms" of organization, i.e., they combine the use of price, authority and trust-based governance mechanisms to organize their exchange relationships. Applying this idea to franchise systems, Bradach and Eccles suggest that franchise systems employ dual distribution not only because some individual outlets are best 
suited for one form and some for the other, but also because the existence of each form positively impacts the management of the other side of the business (see also Harris and Wiens 1980 for a similar argument applied to public and private enterprises). For example, having company owned outlets provides first hand operational insight and credibility that can be used to better manage the franchised outlets. Similarly, having franchised units provides innovative ideas and reality checks on decisions that might remain unchallenged under the authority based management of company-owned chains (see Dant et al. 1992 for a list of benefits of dual distribution specific to franchise systems).

Bradach and Eccles do not include a dynamic process in their analysis of the benefits of the "plural form" in franchise systems. It is clear, however, that many of the suggested benefits are the product of organizational groping for optimal operations, relationships and strategies (Mintzberg 1987). Unlike the financial or incentive based determinants of ownership structure which are apparent ex ante, therefore, the system-specific managerial value of a mix of both company owned and franchised units may be learned over time. Consistent with this argument, Lillis, Narayana and Gilman (1976) found that the advantages of franchising that franchisors identified early in a franchise system's life cycle, such as capital availability, risk sharing, market penetration and even to a lesser extent franchisee motivation, began to diminish as the system reached late maturity. The benefits of a mixed ownership structure, learned through the ongoing management of the system, may act to balance the decreasing importance of the more obvious direct benefits of franchising. If so, these learned synergistic managerial benefits may act to dampen movement toward either full ownership or fully franchised systems. A dynamic learning model of dual distribution in franchised systems, therefore, suggests the following:

H5: The salience of the synergistic managerial benefits provided by the company ownership of outlets will increase with the age of the franchisor.

H6: $\quad$ The salience of the synergistic managerial effects provided by franchisee ownership of outlets will increase with the age of the franchisor.

\section{EXISTING EVIDENCE}

A number of studies have examined changes in ownership patterns in franchising using the aggregate industry level data published for the years 1972-1986 by the Department of Commerce (U.S. Department of Commerce 1988; see Dant et al. 1992 for a review of the empirical evidence on ownership patterns). But the existing empirical evidence at the firm level, the appropriate level of analysis to really address the Oxenfeldt and Kelly (1969) hypothesis, remains quite sparse. To our knowledge, only Ozanne and Hunt (1971), Hunt (1972), Lillis et al. (1976), Martin (1988), Carney and Gedajlovic (1991) and Lafontaine (1992a, b) have examined the contractual mix of individual franchisors. Using cross sectional data, these researchers relied on the comparison of the proportion of company-owned units between old and new franchised businesses at a particular point in time to assess the effect 
of franchisor maturity on the ownership mix. Yet, the Oxenfeldt and Kelly (1969) hypothesis describes how ownership patterns evolve for a given firm as it goes from start-up to maturity. Unfortunately, at this point, the longitudinal data on franchisors' ownership mix that would be most appropriate to test dynamic propositions such as the Oxenfeldt and Kelly hypothesis, remain unavailable.

An alternative strategy, which we follow in this paper, is to use a survey to obtain both cross-sectional and historical information directly from franchisors. The drawbacks associated with this type of data, based on respondent hindsight, are well known (see Fischoff 1975). Still, we believe that this approach yields the best data yet available to analyze the dynamics of ownership patterns. In that sense, we present our results as a first step towards an increased understanding of individual firm dynamics.

\section{THE STUDY}

\section{The Sample}

The sampling frame employed in this study was the membership of the International Franchise Association (IFA). The IFA is the main cross-industry trade association for the franchise industry, and it represents the entire spectrum of franchising companies in the United States and (to a lesser extent) abroad. A total of 603 questionnaires were mailed to the founders or current presidents of U.S. franchise systems. Of these, 5 were returned by the post office as undeliverable, and 15 respondents identified themselves as non-franchisors, i.e., franchise consultants, companies providing services to franchisors, or firms no longer involved in franchising. One hundred and thirty usable questionnaires were returned. The response rate, based on questionnaires reaching potential respondents, was $22 \%$.

To examine the representativeness of the sample, the respondents were compared to the population of franchising companies reported in Franchising in the Economy (IFA and Horwath International 1990). ${ }^{6}$ The average business format franchise company in 1988 (the last date for which there is published data available) had 150 units, with $3 \%$ of the companies having over 1000 units. In our samplc, the avcrage franchisor had 315 units, and cight pcrcent of the respondents had over 1000 units, reflecting a high response rate from large companies. One reason for this upward bias is that the membership list of the IFA reflects a disproportionate number of the well-known, leading franchise companies. This bias suggests that the results of our study may not be generalizable to small franchise systems. However, given our emphasis on evolution, it is important that our sample reflect systems large enough to have begun to experience some relaxation of resource constraints.

The respondents were also compared to the population in terms of the specific industries to which they belong. Table 1 reports the industry breakdown of the sample and the population. The sample appears to fairly represent the population on this criterion. ${ }^{7}$

The sample also closely reflects the recent rapid growth of franchising and the youth of many franchise systems. From data published in Franchising in the Economy, we know that between 1980 and 1986 approximately 1500 new franchise systems were created. This 
TABLE 1

\begin{tabular}{lcc}
\multicolumn{3}{c}{$\begin{array}{c}\text { Distribution of Respondents According to } \\
\text { their Type of Business }\end{array}$} \\
\hline & Sample & Population \\
\hline Auto products \& services & $11.5 \%$ & $10.0 \%$ \\
Business aids \& services & $17.6 \%$ & $16.7 \%$ \\
Construction & $10.8 \%$ & $6.9 \%$ \\
Convenience stores & $1.5 \%$ & $4.8 \%$ \\
Educational & $3.8 \%$ & $3.3 \%$ \\
Restaurants & $15.4 \%$ & $26.3 \%$ \\
Hotels, motels & $6.2 \%$ & $2.8 \%$ \\
Laundry \& dry cleaning & $2.3 \%$ & $0.7 \%$ \\
Recreation & $1.5 \%$ & $2.7 \%$ \\
Auto-truck rental & $0.8 \%$ & $2.8 \%$ \\
Equipment rental & $2.3 \%$ & $0.8 \%$ \\
Non-food retailing & $14.6 \%$ & $13.7 \%$ \\
Non-convenience food retail & $3.8 \%$ & $6.4 \%$ \\
Miscellaneous & $7.7 \%$ & $2.0 \%$ \\
No answer & $0.8 \%$ & \\
\hline
\end{tabular}

represented $68 \%$ of the franchisors reported to be doing business in 1986 . In our sample, sixty percent of the responding franchisors had become involved in franchising in the 1980s.

Perhaps most importantly, the sample closely matches the population in terms of the percentage of company-owned outlets. The population percentage in 1988 was reported as 21.6\% (IFA and Horwath International 1990), while the mean percentage in our sample was $17.8 \%$. The difference between these two means is not significant.

\section{Measures}

The survey instrument contained both structured and open-ended questions. Some of the questions permitted multiple answers. For example, respondents were asked to enumerate the advantages of franchising or owning outlets directly. The answers to these open-ended questions were content analyzed and grouped to capture meaningful constructs while maintaining as much of the rich diversity of the responses as possible. It is important to note, however, that the open-ended question format for some of the measures, though helpful in uncovering unanticipated responses, is influenced heavily by the interest and cooperativeness of the respondents. Fortunately, the high percentage of fully usable questionnaires offers some evidence that this may not have been a serious issue in this study.

Respondents were asked to state their current proportion of company-owned outlets and the proportion that they would like to have in their system (expressed as ranges, see Table 2). These self-reported measures were then supplemented with published data specific to the 
respondent franchisors (Bond and Bond 1991; U.S. Department of Commerce 1991; Entrepreneur 1991; Info Press, Inc. 1991). Measures of the salience of the synergistic managerial benefits of company and franchisee ownership were obtained through open-ended questions asking franchisors what they perceived to be the advantages and disadvantages of franchised and company-owned units (see bottom of Table 3 for the exact questions used). A dummy variable was created for each category of benefits by assigning a value of one to respondents who mentioned the category and zero to those who did not.

Finally, franchisors were asked in the survey to indicate when they started franchising. This information was used to generate our age variable which we use as a surrogate for the degree of system maturity and thus as a measure of a franchisor's greater access to resources (Lillis et al. 1976). Finally, information as to whether the franchise system is a subsidiary of a larger corporation was also obtained directly from the respondents.

\section{Results}

H1A and H1B and H3A and H3B were tested by examining the self-reported desired proportion of company-owned outlets, and then comparing it with the current proportion (see Table 2). No respondent signified that they would like to own and operate $100 \%$ of their outlets, and only two franchisors indicated a preference for owning the majority of their units (Table 2). About one third of the respondents said they would prefer to own none, or less than $5 \%$ of all the units, with twenty-three percent of the franchisors indicated that they would prefer a fully franchised system. The relatively small desired proportions of companyowned units suggests that franchising is preferred as the dominant mode of operation for these firms. This finding is consistent with the incentive argument for franchising, and calls into question the assumed preference for company-ownership inherent in the resource constraint argument. On the other hand, the fact that more than $75 \%$ of the franchisors want

\section{TABLE 2}

\section{Comparison of Desired and Actual Proportions of Company Owned Outlets}

\begin{tabular}{lrrrrrrrr} 
Desired & \multicolumn{8}{c}{ Actual } \\
\hline & $0 \%$ & $1-5 \%$ & $6-10 \%$ & $11-20 \%$ & $21-50 \%$ & $51 \%+$ & No ans. & Total \\
\hline $0 \%$ & 18 & 4 & 0 & 1 & 0 & 0 & 0 & 23 \\
$1-5 \%$ & 6 & 25 & 2 & 3 & 3 & 3 & 0 & 42 \\
$6-10 \%$ & 4 & 5 & 6 & 4 & 4 & 1 & 0 & 24 \\
$11-20 \%$ & 2 & 1 & 2 & 2 & 1 & 2 & 0 & 10 \\
$21-50 \%$ & 1 & 1 & 3 & 0 & 13 & 7 & 0 & 25 \\
$51-99 \%$ & 0 & 0 & 0 & 0 & 1 & 2 & 0 & 3 \\
$100 \%$ & 0 & 0 & 0 & 0 & 0 & 1 & 0 & 1 \\
No ans. & 1 & 0 & 0 & 0 & 0 & 0 & 1 & 2 \\
Total & 32 & 36 & 13 & 10 & 22 & 16 & 1 & 130 \\
\hline
\end{tabular}




\section{TARLE 3}

\section{Synergistic Effects of Dual Distribution}

1. Effects of Franchised Units on the Management of Company-Owned Units (36\% of the respondents mentioned one or both of these benefits)

Franchisees as Sources of New ideas (20\%)

Franchisees as Sources of Objective Input on Franchisor Policies (20\%)

2. Effects of Company-Owned Units on Management of Franchised Units (75\% of the respondents mentioned one or more of the following)

Company-Owned Units as Platforms for Research and Development of Products, Services and Training $(64 \%)$

Company-Owned Units as Sources of Market Information (27\%)

Company-Owned Units as Sources of Credibility among Franchisees (13\%)

Company-Owned Units as Platforms for Development of Standards and Policies (7\%)

Company-Owned Units as Source of Common Bond with Franchisees (2\%)

Notes: The open-ended survey questions used to determine the salience of these synergistic effects for the respondents were:

1. Most franchisors have both franchised and company-owned outlets. Why don't they franchise all their units or operate them all?

2. What advantages might company-operated outlets have in a franchised chain?

3. What advantages do franchised outlets have?

4. What do franchisees provide your organization that company store managers do not?

to operate some units directly suggests that there are some benefits to company-ownership that the incentive-based explanations for franchising do not capture.

Comparing the self-reported desired proportion and the actual proportion of companyowned units, more than half of the respondents (sixty-six) chose the same range for both (see diagonal in Table 2). The remaining respondents were arrayed both above and below the diagonal, with no dominant pattern. Thirty-five franchisors $(27 \%)$ said they were operating above their perceived optimal, while $27(21 \%)$ said they were operating below it. Separating the groups on the basis of their status as a subsidiary or not leads to similar results. Overall, these results provide little support for H1A or H1B (though the data are somewhat more consistent with the latter), or for either lag hypothesis, $\mathbf{H 3 A}$ or $\mathbf{H 3 B}$.

To examine H2A, H2B and H4A, H4B, the parameters of the following equation were estimated:

$$
\% \text { Company owned }=\beta_{0}+\beta_{1} \text { AGE }+\beta_{2}(1 / \text { AGE })+\beta_{3} S U B+\beta_{4}(A G E \times S U B)
$$

The combination of $\mathrm{AGE}$ and (1/AGE) in the equation allows for the possibility of a nonlinear relationship of a form that is most consistent with the pattern one should observe if resource constraints were an important determinant of ownership. (We also tried the exponential functional form, but the chosen form fit the theory and data better, and is more easily interpreted.) The results of the regression are reported in Table 4 . The positive regression coefficients for both $1 / \mathrm{AGE}$ and $\mathrm{AGE}$, and their relative sizes, indicate an initial inverse relationship between the proportion of company-owned outlets and the age of the 


\section{TABLE 4}

\begin{tabular}{c}
$\begin{array}{c}\text { Regression Results: Proportion of Company-Owned Outlets } \\
\text { as Dependent Variable }\end{array}$ \\
\hline
\end{tabular}

\begin{tabular}{lccc}
\hline Adjusted R-Square: 22 & & & \\
$\mathrm{~F}=9.75$ Sig. of $\mathrm{F}=.00$ & & & \\
$\mathrm{n}=122$ & $B$ & $T$ & Sig. $T$ \\
Variable & .007 & 2.11 & .037 \\
\hline AGE $^{\mathrm{a}}$ & .491 & 5.20 & .000 \\
$1 /$ AGE $^{\mathrm{b}}$ & .187 & 2.90 & .004 \\
SUB & -.007 & -1.68 & .095 \\
INTERACT $^{\mathrm{C}}$ & -.065 & -1.12 & .264 \\
(Constant) &
\end{tabular}

Notes: ${ }^{a}$ AGE is defined as the total number of years the franchisor has been in business.

$b_{\text {SUB }}$ is a dummy variable where it equals 1 if the franchisor is a subsidiary of a larger corporation.

CINTERACT is an AGE by SUB interaction term.

system, a relationship that then turns upward after about 16 years. The positive coefficient for SUB shows that the status of subsidiary is predictive of a greater proportion of company-owned outlets. However, the nonsignificant interaction term implies that the slope of the relationship between age and company ownership does not change due to subsidiary status. Combined, these findings provide some support for the resource constraint arguments as reflected in $\mathrm{H2A}$, and $\mathrm{H4A}$.

Our survey also provided firm by firm data on how the proportion of company-owned units changed since the system first began franchising. ${ }^{8}$ This allowed us to examine the validity of H2A and H2B from a somewhat different perspective, namely from self-reported historical data. Interestingly, only 76 out of the 130 respondents reported a change in the proportion of company-owned units. (It is likely that some of the other 54 respondents meant either that the proportion had not changed much or that the number of company-owned units had not changed. These answers illustrate well some of the difficulties inherent in obtaining self-reported data based on hindsight.) Of those who indicated that this proportion had changed, more than half ( 40 of 76 ) said that it had decreased over the franchising life of the company. Another $15(20 \%)$ said that it had increased, while 14 franchisors said that it had varied with no clear pattern. Only one respondent said that it went down and then up, the pattern one would expect to find if franchisors first develop prototype company-owned units, then use franchising to get access to resources to expand, and finally reduce their reliance on franchising as their resource constraints become more relaxed.

Turning to Bradach and Eccles' (1988) notion that there might be synergistic benefits derived from having both company-owned and franchised units in the same system, the data in Table 2 are supportive of this idea in that they show that most franchisors desire a mix of both company-owned and franchised units. The respondents' focus, however, seems to be on the way that the presence of company-owned units in the system can assist in the successful management of the franchised units. While only $36 \%$ of the franchisors mentioned 


\section{TABLE 5}

Relationship of System Age to Advantages of Dual Distribution

\begin{tabular}{llcccc}
\hline & & Mean Age & Std.D. & t-val & Sig. \\
\hline $\begin{array}{l}\text { A. H5: } \\
\begin{array}{l}\text { Mentioned Synergy Effect of } \\
\text { Company-Owned Outlets }\end{array}\end{array}$ & $\begin{array}{l}\text { No } \\
(\mathrm{n}=32)\end{array}$ & 12.8 & 12.4 & & \\
& $\begin{array}{l}\text { Yes } \\
(\mathrm{n}=96)\end{array}$ & 9.6 & 9.3 & $\begin{array}{c}1.33 \\
(\mathrm{df}=43)\end{array}$ & .094 \\
$\begin{array}{l}\text { B. H6: } \\
\begin{array}{l}\text { Mentioned Synergy Effect of } \\
\text { Franchised Outlets }\end{array}\end{array}$ & $\begin{array}{l}\text { No } \\
(\mathrm{n}=86)\end{array}$ & 9.0 & 9.0 & & \\
& $\begin{array}{l}\text { Yes } \\
(\mathrm{n}=46)\end{array}$ & 13.2 & 12.0 & & \\
& & & & & \\
$(\mathrm{df}=64)$ & & \\
\hline
\end{tabular}

the positive impact of franchised outlets on the company-owned side of the business, $75 \%$ mentioned the positive impact of company-owned outlets on the management of the franchised side.

H5 and $\mathrm{H6}$ were tested directly by comparing the mean age of the group of respondents that recognized the synergistic benefits of company-owned and franchised outlets with the mean age of those that did not. Results from that comparison are shown in Table 5. The mean age of the group that mentioned synergistic benefits from some company ownership was somewhat lower (significant at the .1 level), than the group that didn't (H5). At the same time, the age of the group that mentioned synergistic benefits from some franchisee ownership was significantly greater on average than the age of the group that didn't (H6). These results suggest that the synergistic benefits of company-owned units become apparent earlier in a system's history, while the synergistic effects of franchisee-owned units are recognized only later in a franchisor's life cycle.

\section{RELATED FINDINGS}

Although the ownership mix is perhaps the single most important feature of franchised systems (or the one that has generated the most research), other critical components of the franchisor-franchisee relationship are the sets of rights and obligations that define the governance of the system. Modern business practice has tended to minimize the centrality of formal contract (Macaulay 1963). However, in franchising the formal agreement is a vital and highly specific document (see, for example, Udell 1972; Noordewier 1991). By reference, the agreement also often incorporates lengthy operations manuals with rigid standards of quality and performance through which the franchisor can provide new, inexperienced franchisees with a guide to the best practice available (Kaufmann and Leibenstein 1988). Our survey yielded some useful information relative to the way in which 
various components of the franchise contract evolve as the franchisor's system matures. We now turn to a brief description of those results.

Managing uniform quality within a franchise system tends to require some degree of uniformity across franchise agreements. Prior empirical work has revealed that franchise contracts are often "contracts of adhesion rather than balanced, negotiated agreements" (Hunt 1972). Our findings are generally consistent with this statement. Ninety-seven percent of the respondents to the survey said that they offered the same standard franchise contract to all their potential franchisees at a given point in time. Moreover, forty-four percent of the respondents indicated that the contracts they offered to franchisees were on a take-it-orleave-it basis, leaving no room whatsoever for negotiation. Where some room was left for negotiation, it was not allowed with respect to monetary terms, such as royalty rates and franchise fees, but focused instead on non-monetary terms. ${ }^{9}$ The franchisors allowing such negotiation were significantly younger than those that did not. Apparently, franchisors are more willing to permit diversity of obligations early in their systems' development than after they have gained experience and the concept has solidified.

Although there was much uniformity in the franchise fees and royalty rates offered to franchisees at a given point in time, these fees did change as the systems matured. Seventyone percent of the responding franchisors reported having modified their franchise fees at least once during the life of their system, and 52\% reported having changed their royalty rates. Viewed from another perspective, however, these results suggest a fairly high degree of stability. Twenty-nine percent of the respondents say that their franchise fee has never been modified since they first became involved in franchising (not even to keep up with inflation), and $48 \%$ have never changed their royalty rate. It should be noted, however, that almost all $(89 \%)$ of those franchise systems with no change in their franchise fees had become involved in franchising in the 1980s.

Respondents reported that adjustments to their franchise fees were triggered mostly by changes in the market demand for the franchise rights and by changes in the cost of running the system. They attributed adjustments to the royalty rates to changes in the cost of running the system, in market demand, and in the value of the trademark.

Finally, one key theoretical question in franchising involves the link between the franchise fee and royalty rate. It has been suggested that these forms of payment can be used in various combinations to provide appropriate incentives (Rubin 1978; Lal 1990; Bhattacharyya and Lafontaine 1992). Assuming that the combinations of franchise fees and royalty rates leave franchisees at their reservation utility, as most of the existing agency models imply, the two should be negatively correlated. However, in cross-sectional analyses, Lafontaine (1992a,b) and Banerji and Simon (1992) did not find this negative correlation. Sen (1993), on the other hand, found some support for the notion that factors that affect royalty rates positively simultaneously affect franchise fees negatively. Our survey allowed us to extend these analyses by examining whether adjustments to the franchise fee and royalty rates are negatively correlated. We found that for those franchisors that changed both their franchise fees and royalty rates as their system matured, eighty-three percent of the changes were in the same direction. More specifically, in all these cases the franchise fees and royalty rates were both increased. In $14 \%$ of the cases, the royalty rates went down while franchise fees went up, and vice versa for the remaining $3 \%$ of the cases. One possible reason for the strength of the positive relationship found between increases in royalties and franchise fees 
is the increasing value of the franchise itself. The hypothesized negative correlation holds the value of the franchise constant. Here, the passage of time and the growth of the sampled systems may be acting to create a dynamic process not modelled in the standard analysis.

\section{CONCLUSION}

The primary purpose of this study was to gain insight into the evolution of the ownership structure of franchised chains. Although longitudinal data were not available for this study, the firm-level, primary data reported here is a significant improvement over the industry level analyses typical of research in the area (Dant et al. 1992).

Our results support the notion that resource constraints might play a role in determining the extent to which franchisors own outlets. Both the fact that firms tended to increase their proportion of company-owned units when they reached about 16 years of age, and the fact that franchisors that were subsidiaries of larger corporations owned more of their own units, point toward the idea that access to resources might constrain some firms to operate less units than they would like. However, it is also clear from the data that the franchisors in this study intend to continue to operate a mix of company-owned and franchised outlets, with the sought proportion of company-owned units being relatively small. This later tendency, towards a relatively limited use of company-ownership, suggests that franchising is indeed the generally preferred mode of operation for these firms, presumably because of its incentive properties. The fact that franchisors could identify synergistic effects associated with company-owned units most likely explains why they want to own some units despite the better incentive structure achieved through franchising. In other words, as heavily franchised systems experience a relaxation of their resource constraints and become more able to expand through company-ownership, they may do so only to take advantage of the plural form benefits and not at all in an attempt to reach the near complete ownership envisioned by Oxenfeldt and Kelly.

Among the related findings, we found that there is a strong preference for uniformity of franchise contracts across all franchisees, and that franchisors negotiate their franchise agreements only when compelled to do so. Only about half of the respondents ever agreed to negotiate some (almost always non-monetary) aspect of their contract. The newer and presumably less powerful franchisors are more likely to engage in this type of negotiation.

We also found that contract terms do change over the life of the system. Changes in franchise fees and royalty rates were driven by both demand and cost changes. The most interesting finding regarding the changes in fees and royalties was the fact that they tend to increase simultaneously. Although this finding may be due to increases in the value of the franchises (an effect for which we did not control), it might also have implications for economic theory which strongly suggests the negative interdependence of these fees.

This paper has begun the process of understanding the dynamics of franchise systems. Their evolution, especially as it relates to the change in ownership patterns, is important not only to franchising researchers, but also to policy makers, and to franchise managers. The current interest in increased franchise legislation is a direct result of presumed changes in ownership patterns and the implied opportunistic behavior of franchisors. Time-series, firm-level data are critical to the accurate assessment of these phenomena. This study is offered as a first step in that direction. 


\section{NOTES}

1. There have also been a few models based on information asymmetry or "hidden characteristics" in the principal-agent literature. See notably Gallini and Lutz (1992).

2. Franchisors usually start out with some company operated prototypes. Hence these firms are $100 \%$ company-owned when they start franchising. As a result, this proportion (of company-owned outlets) can only go down originally. As the system becomes more mature however, according to Oxenfeldt and Kelly, we should find that the proportion of company-owned outlets begins to increase.

3. Incentives for franchisee performance have typically been derived from either residual claimancy rights or from forfeitable bonds (e.g., Klein 1980; Klein and Saft 1985; Klein and Murphy 1988). Kaufmann and Lafontaine (1994) make the case that residual claimancy rights and bonds (or forfeitable rents) may be used together to create the right set of incentives.

4. This would especially be the case if all outlets were "similar" in terms of market potential and other relevant characteristics. Theoretically, in this case, the optimal solution would be to franchise all outlets under the same contract terms. If the outlets were heterogeneous, then all outlets optimally would be franchised under different franchise agreements. If however outlets were heterogeneous, and the firm could use only one franchise contract, it might find it optimal to operate directly those units whose optimal contract would involve a very high royalty rate.

5. The signaling hypothesis, proposed notably by Gallini and Lutz (1992), also suggests a shift toward franchising as a franchise system matures. However, Lafontaine 1992a finds little empirical support for this explanation for franchising in her empirical analyses.

6. Franchising in the Economy was originally published by the Department of Commerce. This publication was suspended in 1988 as part of the government's privatization program. As a result, 1986 is the last year for which this information is available from the US Government. In 1990, the Educational Foundation of the International Franchise Association, in conjunction with Horwath International, published a new version of this annual survey. Their results for 1988 were based on 2239 respondents.

7. When categories were grouped so that the expected size of each cell was more than five (Kinnear and Taylor 1991), the under-representation of restaurants in the sample, and the over-representation of respondents in the miscellaneous category, produced a significant Chi-Square overall. How this pattern should bias the results is not obvious.

8. We asked franchisors "Has the proportion of company-owned outlets changed in your firm since you first adopted franchising?" and "If yes, how has it changed?" Possible answers included: Increased Steadily; Decreased Steadily; Went Down then Up; Varied without a Clear Pattern; Other, Please Explain.

9. Only 14 of 130 respondent franchisors indicated that they permitted negotiation of some monetary terms, and they did not differ in age from those that did not negotiate.

\section{REFERENCES}

Banerji, Shumeet and Carol J. Simon (1992). "Franchising Versus Ownership." Working paper, University of Chicago.

Bergen, Mark, Shantanu Dutta and Orville C. Walker, Jr. (1992). "Agency Relationships in Marketing: A Review of the Implications and Applications of Agency and Related Theories," Journal of Marketing, 56(3): 1-24. 
Bhattacharyya, Sugato and Francine Lafontaine (1992). "Double-Sided Moral Hazard and Franchising." Working paper \#698, Division of Research, School of Business Administration, University of Michigan.

Blair, Roger D. and David L. Kaserman (1982). “Optimal Franchising”, Southern Economic Journal, (October): 494-504.

Bond, Robert E. and Christopher E. Bond (1991). The Source Book of Franchise Opportunities, 1990-1991 Edition. Homewood, IL: Dow Jones-Irwin.

Bradach, Jeffrey L. and Robert G. Eccles (1989). "Price, Authority and Trust: From Ideal Types to Plural Forms," Annual Review of Sociology, 15: 97-118.

Brickley, James A. and Frederick H. Dark (1987). "The Choice of Organizational Form: The Case of Franchising," Journal of Financial Economics, 18: 401-420.

Bush, Ronald F., Ronald L. Tatham and Joseph F. Hair, Jr. (1976). "Community Location Decisions by Franchisors: A Comparative Analysis," Journal of Retailing, 52(1): 33-42,93.

Carney, M. and E. Gedajlovic (1991). "Vertical Integration in Franchise Systems: Agency Theory and Resource Explanations," Strategic Management Journal, 12: 607-629.

Caves, Richard E. and William F. Murphy II (1976). "Franchising: Firms, Markets, and Intangible Assets," Southern Economic Journal, 42(April): 572-586.

Dant, Rajiv P. (1994). "Motivations for Franchising: Rhetoric Versus Reality." Working paper, Boston University.

Dant, Rajiv P., Patrick J. Kaufmann and Audhesh K. Paswan (1992). "Ownership Redirection in Franchised Channels," Journal of Public Policy and Marketing, 11(1): 33-44.

Entrepreneur (1991). 12th Annual Franchise 500, 19(1): 113-208.

Fischoff, Baruch (1975), "Hindsight $\neq$ Foresight: The Effect of Outcome Knowledge on Judgement Under Uncertainty," Journal of Experimental Psychology: Human Perception and Performance, 1(3): 288-299.

Gallini, Nancy T, and Nancy A. Lutc (1992). "Dual Distribution and Royalty Fees in Franchising," Journal of Law, Economics and Organization, 8: 471-501.

Gilman, Alan L. (1990). "Competitive Growth with Franchising," Chain Store Age Executive, (January): 160.

Harris, Richard G. and Elmer G. Wiens (1980). "Government Enterprise: An Instrument for the Internal Regulation of Industry," Canadian Journal of Economics, 8(1): 125-132.

Hunt, Shclby D. (1972). "The Sociocconomic Consequences of the Franchisc System of Distribution," Journal of Marketing, 36(July): 32-38.

Info Press, Inc (1991). The Franchise Annual. Lewiston, NY: Info Press.

International Franchise Association and Horwath International (1990). Franchising in the Economy. Washington, DC: International Franchise Association.

Kaufmann, Patrick J, and Francine Lafontaine (1994). "Costs of Control: The Source of Economic Rents for McDonald's Franchisees," Journal of Law and Economics, 37(2): (Forthcoming).

Kaufmann, Patrick J. and Harvey Leibenstein (1988). "International Business Format Franchising and Retail Entrepreneurship: A Possible Source of Retail Know-How for Developing Countries," Journal of Development Planning, 18: 165-182.

Kinnear, Thomas and James Taylor (1991). Marketing Research. New York: McGraw Hill.

Klein, Benjamin (1980). "Transaction Costs Determinants of "Unfair" Contractual Arrangements," American Economic Review, 70: 356-362.

Klein, Benjamin and K.M. Murphy (1988). "Vertical Restraints as Contract Enforcement Mechanisms," Journal of Law and Economics, 31: 265-297.

Klein, Benjamin and L.F. Saft (1985). "The Law and Economics of Franchise Tying Contracts," Journal of Law and Economics, 28: 345-361. 
Lafontaine, Francine (1992a). "Contract Theory and Franchising: Some Empirical Results," Rand Journal of Economics, 23: 263-283.

(1992b). "How and Why Do Franchisors Do What They Do: A Survey Report," in Franchising Passport for Growth \& World of Opportunity, P.J. Kaufmann (ed.), 1992 Proceedings of the Society of Franchising. Lincoln, NE: International Center for Franchise Studies, University of Nebraska.

Lal, Rajiv (1990). "Improving Channel Coordination through Franchising," Marketing Science, 9: 299-318.

Lillis, Charles M., Chem L. Narayana and John L. Gilman (1976). "Competitive Advantage Variation Over the Life Cycle of a Franchise," Journal of Marketing, 40(October): 77-80.

Macaulay, Stewart (1963). "Non-Contractual Relations in Business: A Preliminary Study," American Sociological Review, 28: 55-67.

Martin, Robert E. (1988). "Franchising and Risk Management," The American Economic Review, 78(5): 954-968.

Mathewson, G. Frank and Ralph A. Winter (1985). "The Economics of Franchise Contracts," Journal of Law and Economics, 28(October): 503-526.

Minkler, Alanson P. (1990). "An Empirical Analysis of a Firm's Decision to Franchise," Economic Letters, 34: 77-82.

Mintzberg, Henry (1987). "Crafting Strategy," Harvard Business Review, (July-August); 66-77.

Muris, Timothy J. (1981). "Opportunistic Behavior and the Law of Contracts," Minnesota Law Review, 65: $52,521-590$.

Noordewier, Thomas G. (1991). "The Organization of Franchise Contracts: An Economic Perspective." In Franchising: Embracing the Future, J.R. Nevin (ed.), 1991 Proceedings of the Society of Franchising. Lincoln, NE: International Center for Franchise Studies, University of Nebraska.

Norton, Seth W. (1988). "An Empirical Look at Franchising as an Organizational Form," Joumal of Business, 61: 197-217.

Oxenfeldt, Alfred R. and Anthony O. Kelly (1969). "Will Successful Franchise Systems Ultimately Become Wholly-Owned Chains?," Journal of Retailing, 44: 69-87.

Ozanne, Utban B. and Shelby D. Hunt (1971). The Economic Effect of Franchising, U.S. Senate, Select Committee on Small Business. Washington: Government Printing Office.

Rubin, Paul (1978). "The Theory of the Firm and the Structure of the Franchise Contract," Journal of Law and Economics, 21(April): 222-233.

Sen, Kabir C. (1993). "The Use of Initial Fees and Royalties in Business Format Franchising," Managerial and Decision Economics, 14: 175-190.

Udell, Gerald (1972). "Anatomy of a Franchise Contract," Cornell Hotel and Restaurant Administration Quarterly, 13(3): 13-21.

U.S. Department of Commerce (1988). Franchising in the Economy. Washington, DC: Department of Commerce.

Williamson, Oliver E. (1985). The Economic Institutions of Capitalism. New York: Free Press. 